\title{
CYTOTOXIC ACTIVITY OF ALKALOIDS EXTRACTED FROM THREE IRAQI PLANTS AGAINST BREAST CANCER CELL LINE
}

\author{
FARAHA AL-MARZOOK, RABAB OMRAN*
}

Department of Biology, College of Science, University of Babylon, Babylon, Iraq. Email: omranaljelawi@gmail.com

Received: 13 April 2017, Revised and Accepted: 19 May 2017

\section{ABSTRACT}

Objectives: Screening for cytotoxic activity of total alkaloid extracts of Eucalyptus camaldulensis, Aloe vera, and Capparis spinosa against breast cancer cell line Michigan Cancer Foundation-7 (MCF-7) and nontumorigenic fetal hepatic cell line (WRL-68).

Methods: The plant powders were extracted separately with $80 \%$ methanol and chloroform at pH 2 and 10 . Total alkaloids were detected qualitatively by Mayer's, Dragendorff's, and Hager's reagents and estimated quantitatively by bromocresol green spectrophotometry depending on the atropine calibration curve. The cytotoxic activity was evaluated by 3-[4,5-dimethylthiazoyl]-2, 5-diphenyltetrazolium bromide assay.

Results: The extract of $E$. camaldulensis had highest total alkaloid content $(24.50 \pm 1.70 \mathrm{mg} / 100 \mathrm{~g}$ plant dry weight) than the others. The total alkaloids $(400 \mu \mathrm{g} / \mathrm{ml})$ of $E$. camaldulensis reduced the cell viability of both cell lines MCF-7 and WRL- 68 to $45.25 \pm 2.20 \%$ and $92.00 \pm 1.55 \%$, respectively, and the inhibitory concentration $50 \%$ of cells were $375.50 \mu \mathrm{g} / \mathrm{ml}$ for MCF-7. The alkaloids of $C$. spinosa had effect $79.80 \pm 7.08 \%$ and $89.50 \pm 0.09 \%$ against MCF-7and WRL-68, respectively. While the total alkaloids of $A$. vera had slightly effect on both cell lines.

Conclusion: Plant alkaloids appeared variable cytotoxic activity against cancer and normal cell lines depending on the alkaloid contents, concentrations, purity, and cell line types.

Keywords: Alkaloids, Eucalyptus camaldulensis Dehnh., Aloe vera L., Capparis spinosa L., In vitro, Cytotoxicity, Breast cancer.

(C) 2017 The Authors. Published by Innovare Academic Sciences Pvt Ltd. This is an open access article under the CC BY license (http://creativecommons. org/licenses/by/4. 0/) DOI: http://dx.doi.org/10.22159/ajpcr.2017.v10i9.19134

\section{INTRODUCTION}

Cancer is a major global health problem and is currently classified as the third leading to death after infectious diseases and cardiovascular [1]. Breast cancer is the second most continual cancer effect on people worldwide and the most common cancer among females [2]. In Iraq, breast cancer is the first kind in female, accounting for approximately one-third of the registered female cancers, according to the latest Iraqi Cancer Registry [3]. The history of the plant as a source of anticancer agents started in serious in the 1950s with the detection and development of the vinca alkaloids [4] and the isolation of the cytotoxic podophyllotoxins. The investigations show that Aloe vera contains over 75 nutrient and 200 active phytochemical compounds, including phenol, alkaloid, flavonoid, vitamins, enzymes, minerals, sugar, lignin, anthraquinones, saponins, salicylic acid and amino acids, which are responsible for its medicinal properties [5]. This compound has multiple medicinal properties such as anti-inflammatory, antibacterial, antioxidant, immune boosting, anticancer, antiageing, sunburn relief, and antidiabetic potentials [6]. Capparis spinosa is recognized as a rich source of a wide array of phytochemical compounds in different parts has pharmacological actions, and therapeutic properties have also which include the treatment of diabetes, high blood pressure and liver, spleen and kidney disorders [7,8]. The plant seeds also contain a protein that inhibits the multiplication of hepatoma Hep G2 cells, colon cancer HT29 cells and breast cancer Michigan Cancer Foundation-7 (MCF-7) cells. The reported medicinal health functions and nutritional attributes of $C$. spinosa can be mainly attributed to the occurrence of alkaloids, glucosides, reducing sugars, essential fatty acids, organic acids, vitamin C, terpenoids, flavonoids, and resins in the fruit and leaves of this species [9]. C. spinosa is importance due to the presence of several classes of medicinally important alkaloids along with potential antioxidant compounds [10], it is a rich source of different classes of alkaloids which include spermidine, indole and pyrrole alkaloids along with indol-aldehyde and indol-nitrile type derivatives. Several new alkaloids and their glycosides have also been identified in C. spinosa. Eucalyptus camaldulensis has phytochemicals compound in various parts have medical properties were investigated using standard methods of phytochemicals screening this compound including tannins, saponins, glycosides, steroids and anthraquinones, alkaloids, flavonoids, and terpenoids [11]. The Eucalyptus extract may be considered as a potent anticancer. It reduced the tumor growth. Some this phytochemical compound in plants is toxic [12]. The objective of our study was investigated the cytotoxic activity of total alkaloid extracts of three plants, including $E$. camaldulensis, $A$. vera, and C. spinosa against breast cancer cell line MCF-7 and non-tumorigenic fetal hepatic cell line (WRL-68).

\section{MATERIALS AND METHODS}

Plants collection

The plants (E. camaldulensis Dehnh., A. vera L., C. spinosa L.) were collected from the gardens of University of Babylon, Hilla, Iraq, during March and May 2015

The plants were classified by specialists in the Botanical Garden at University of Babylon (Table 1).

The plant parts were washed with tap water to remove dust and then with distilled water (DW), and dried under shade for 10 days at

Table 1: The studied plants

\begin{tabular}{|c|c|c|c|}
\hline Plant & Family & $\begin{array}{l}\text { Common } \\
\text { name }\end{array}$ & Part used \\
\hline $\begin{array}{l}\text { Aloe vera } \mathrm{L} . \\
\text { Capparis spinosa } \mathrm{L} . \\
\text { Eucalyptus camaldulensis } \\
\text { Dehnh. }\end{array}$ & $\begin{array}{l}\text { Asphodelaceae } \\
\text { Capparaceae } \\
\text { Myrtaceae }\end{array}$ & $\begin{array}{l}\text { Aloe } \\
\text { Caper } \\
\text { Murray } \\
\text { red gum }\end{array}$ & $\begin{array}{l}\text { Leaves } \\
\text { Fruits } \\
\text { Bark }\end{array}$ \\
\hline
\end{tabular}


room temperature. Each dried part was ground and stored in an airlight container to prevent the humidity effect and then stored at room temperature until further use.

\section{Total alkaloid extraction}

Total alkaloids were extracted according to Harborne [13]. Briefly, $20 \mathrm{~g}$ of plant dry powder was extracted with $80 \%$ methanol for $24 \mathrm{~h}$ in a continuous extraction by soxhlet apparatus $250 \mathrm{ml}$ volume. The extract was filtered by Whatman No. 1 filter paper, and then, the filtrate was concentrated by a rotary evaporator under vacuum at $45^{\circ} \mathrm{C}$ until the solution reached to $10 \mathrm{ml}$. Subsequently, the concentrated extract was transferred to a separating funnel and $2 \mathrm{~N} \mathrm{HCl}$ was added gradually to adjust the $\mathrm{pH}$ value up to 2 , after that the extract was washed with $10 \mathrm{ml}$ chloroform three times. Then, the $\mathrm{pH}$ value of the extract was adjusted to 10 using $\mathrm{NH}_{4} \mathrm{OH}$, and partitioned with $10 \mathrm{ml}$ chloroform 3 times. The chloroform portion was dried to obtain the total alkaloid extract. The dried extract was weighed and preserved in a clean container at $4^{\circ} \mathrm{C}$ for further investigation.

\section{Qualitative detection of alkaloids}

To detect the presence of alkaloids in plant extracts some qualitative tests were performed using Mayer's, Dragendorff's and Hager's reagents. Mayer's reagent used to screen all types of alkaloids, prepared by dissolving $13.5 \mathrm{~g}$ of mercuric chloride and $5 \mathrm{~g}$ of $\mathrm{KI}$ in $1000 \mathrm{ml}$ distilled water. The test was done by adding $1-2 \mathrm{ml}$ of the reagent to $5 \mathrm{ml}$ of plant extract. The formation of white or creamy precipitate indicated the test was positive [14]. Furthermore, Dragendorff's reagent was used to investigate alkaloids in plant extract. The reagent was prepared by dissolving $20 \mathrm{~g}$ of bismuth nitrate in $40 \mathrm{ml}$ distilled water and $16 \mathrm{~g}$ of sodium iodide in $40 \mathrm{ml}$ distilled water, and then the two solutions were mixed together. The test was performed by adding $1-2 \mathrm{ml}$ of Dragendorff's reagent in $5 \mathrm{ml}$ of the plant extract; the formation of a prominent orange color indicated the test was positive [15]. Hager'stest, Hager's reagent is saturated solution of picric acid, was done by adding a few drops of the reagent to plant extracts and appeared a yellow color precipitate that indicate to the presence of alkaloids [16].

\section{Estimation of total alkaloid content}

The total alkaloid content was estimated by bromocresol green (BCG) spectrophotometry method $[17,18]$. The BCG reagent was prepared by heating $69.8 \mathrm{mg}$ of BCG with $3 \mathrm{ml}$ of $2 \mathrm{~N} \mathrm{NaOH}$ and $5 \mathrm{ml}$ distilled water until completely dissolved, and then, the solution was diluted to $1000 \mathrm{ml}$ with distilled water. Phosphate buffer solution ( $\mathrm{pH}$ 4.7) was prepared by adjusting the $\mathrm{pH}$ of $2 \mathrm{M}$ sodium phosphate $\left(71.6 \mathrm{~g} \mathrm{Na}_{2} \mathrm{HPO}_{4}\right.$ in 1 distilled water) to 4.7 with $0.2 \mathrm{M}$ citric acid (42.02 g citric acid in 1 distilled water).

\section{BCG assay}

A $10 \mathrm{mg}$ of the plant extract was dissolved in $2 \mathrm{~N} \mathrm{HCl}$ and then filtered. $1 \mathrm{ml}$ of this solution was transferred to separator funnel and washed with $10 \mathrm{ml}$ chloroform (3 times). The $\mathrm{pH}$ of this extract was adjusted to neutral with $0.1 \mathrm{~N} \mathrm{NaOH}$. Then, $5 \mathrm{ml}$ of BCG solution and $5 \mathrm{ml}$ of phosphate buffer were added to the extract. The mixture was shaken and the complex extracted with 1,2,3, and $4 \mathrm{ml}$ chloroform by vigorous shaking; the extract was then collected in a $10 \mathrm{ml}$ volumetric flask and diluted with chloroform. The absorbance of the complex in chloroform was measured at $470 \mathrm{~nm}$ against blank prepared as above but without alkaloid or plant extract. The total alkaloids were calculated depending the calibration curve of atropine [17].

\section{Cytotoxic activity}

This assay was held at the Centre for Natural Product Research and Drug Discovery, Department of Pharmacology, Faculty of Medicine, University of Malaya/Kuala Lumpur, Malaysia.

The cytotoxic activity was assayed against two kinds of cell linesincluding breast cancer cell line MCF-7 and nonmutagenic fetal hepatocyte WRL-68 using 3-[4, 5-dimethylthiazoyl]-2, 5-diphenyltetrazolium bromide (MTT dye). Briefly, $100 \mu \mathrm{l}$ cell suspension was added onto the flat-bottomed micro-culture plate wells, separated plate for each cell line in triplicate, and treated them with $100 \mu \mathrm{l}$ partially purified plant extract, incubated for $24 \mathrm{~h}$, centrifuged to remove the dead cells. Aliquot of $100 \mu \mathrm{l}$ of $2 \mathrm{mg} / \mathrm{ml}$ MTT dye was added to each well, and the incubation was continued for a further $4 \mathrm{~h}$, then $50 \mu \mathrm{l}$ of solubilization solution of dimethyl sulfoxide was added into each well. After complete solubilization of the dye, the absorbance of was read at $620 \mathrm{~nm}$ with an enzyme-linked immunosorbent assay reader. The mean absorbance for each group of replicates was calculated. The percentage viability of cells exposed to various treatments was calculated as follows [19]:

$\%$ Cell viability $=\frac{\text { Mean absorbance of treated sample }}{\text { Meanabsorbance of non-treated sample }} \times 100$

The control was the non-treated cultures in all experiments that contained cells in the medium only.

\section{Statistical analysis}

Statistical analysis of the data was performed using SPSS using one-way analysis of variance according to the method described by Levesque [20] numerical data were expressed as mean \pm standard deviation. $\mathrm{p}<0.05$ was considered to be statistically significant.

\section{RESULTS}

Table 2 showed the qualitative detection of alkaloids present in three plant extracts using different reagent. The qualitative analysis of all extracts appears the presence of alkaloids by changing color in each reagent. The results of extraction yields of chloroform extracts were presented in Table 3. The soxhlet extraction procedure using the chloroform and methanol solvent showed that the total alkaloid of the E. camaldulensis bark was $24.50 \pm 1.70 \mathrm{mg} / 100 \mathrm{~g}$ DW of plant, which was higher than $A$. vera leaves and C. spinosa fruits were $16.50 \pm 1.00$ and $13.35 \pm 1.00$, respectively. Fig. 1 showed the effects of the total alkaloid extract of E. camaldulensis bark treatment against MCF-7 and WRL-68. The growth of cancer cell was inhibited at low concentration with an eventual decline at the highest concentrations tested. It was given cell viability $45.25 \pm 2.20 \%, 78.70 \pm 2.67 \%, 92.00 \pm 3.19 \%, 94.90 \pm 6.20 \%$ at alkaloid concentrations $400,200,100,50 \mu \mathrm{g} \backslash \mathrm{ml}$ respectively, in comparison with the cell viability of normal cell $(92.00 \pm 2.10 \%$, $97.29 \pm 0.67 \%, 94.20 \pm 2.90 \%$, and $97.87 \pm 1.50 \%$, respectively) in the same concetration. The inhibitory concentration $50 \%\left(\mathrm{IC}_{50}\right)$ of MCF-7 cell line equal $375.5 \mu \mathrm{g} / \mathrm{ml}$ of alkaloid extract. The second alkaloid extract (C. spinosa fruits) in this study reduced the cell viability of the MCF-7 cell line was $79.80 \pm 7.08 \%$ with $400 \mu \mathrm{g} \backslash \mathrm{ml}$, and the $\mathrm{IC}_{50}$ was $991.50 \mu \mathrm{g} \backslash \mathrm{ml}$ (Fig. 2). Whereas, Fig. 3 showed the cell viability of the cancer cells did not inhibit in comparison with the normal cell when

Table 2: Qualitative detection of alkaloids in plant extract using different reagents

\begin{tabular}{lll}
\hline Reagent & Result & Resulted color \\
\hline Mayer's reagent & + & Creamy precipitate \\
Dragendorff's reagent & + & Orange color \\
Hager's reagent & + & Yellow color \\
\hline
\end{tabular}

+ : Indicate the positive results

Table 3: The total alkaloid contentsof tested plant

\begin{tabular}{lll}
\hline Plant & Parts & $\begin{array}{l}\text { Total alkaloid content } \\
\mathbf{m g} / \mathbf{1 0 0} \text { g of plant } \\
\mathbf{D W} \mathbf{\text { SD }}\end{array}$ \\
\hline $\begin{array}{l}\text { Eucalyptus camaldulensis } \\
\begin{array}{l}\text { Dehnh. } \\
\text { Aloe vera } \text { L. }\end{array}\end{array}$ & Bark & $24.50 \pm 1.70$ \\
Capparis spinosa L. & Leaves & $16.50 \pm 1.00$ \\
\hline
\end{tabular}

The results represent as a $\mathrm{mg} / 100 \mathrm{~g}$ of plant $\mathrm{DW} \pm$ standard deviation , the mean difference is significant at the 0.05 level. DW: Distilled water 


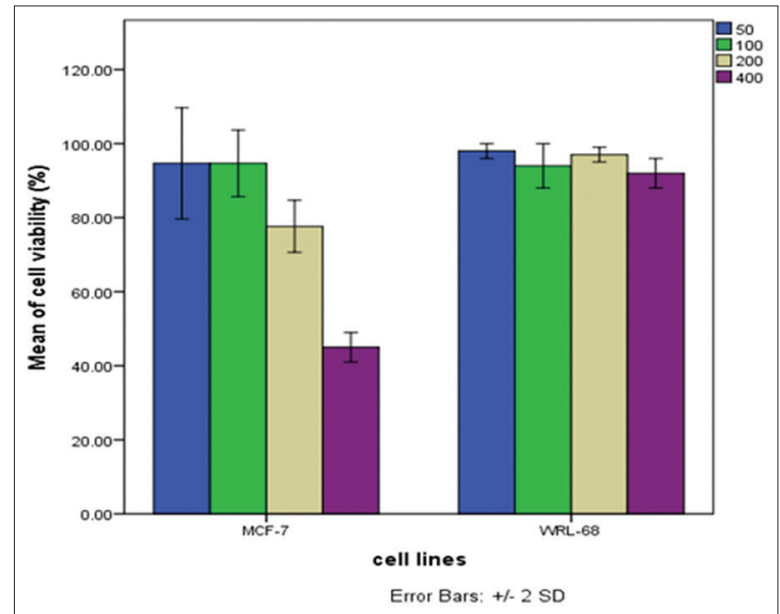

Fig. 1: Cytotoxic activity of the total alkaloids of Eucalyptus camaldulensis bark against the WRL-68 and Michigan Cancer Foundation-7 (MCF-7) cell lines. Extract concentrations ranged from 50 to $400 \mu \mathrm{g} / \mathrm{ml}$ and inhibitory concentration $50 \%$ of MCF-7 was $375.50 \mu \mathrm{g} / \mathrm{ml}$

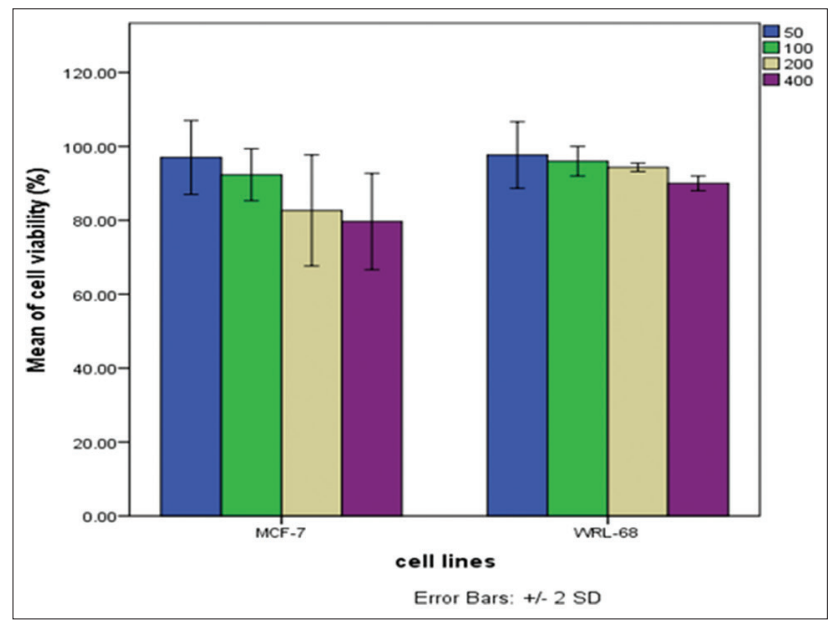

Fig. 2: Cytotoxic activity of the total alkaloids of Capparis spinosa leaves against the WRL-68 and Michigan Cancer Foundation-7 (MCF-7) cell lines. Extract concentrations ranged from 50 to $400 \mu \mathrm{g} / \mathrm{ml}$ and inhibitory concentration $50 \%$ of MCF-7 was $879.20 \mu \mathrm{g} / \mathrm{ml}$

treated with the alkaloid extract of $A$. vera leaves; it was $97.70 \pm 2.67 \%$, $98.37 \pm 3.00 \%, 104.00 \pm 2.70 \%$, and $102.00 \pm 0.75 \%$ with treating 400 , 200 , and $100,50 \mathrm{~g} \backslash \mathrm{ml}$.

\section{DISCUSSION}

Medicinal plants contain some organic compounds which provide definite physiological action on the human body, and these bioactive substances include tannins, alkaloids, carbohydrates, terpenoids, steroids, and flavonoids [21]. Alkaloid in three plants was extracted using methanol and chloroform solvents, and the total alkaloids were detected by changing the color of specilized reagents. Alkaloid quantities were different among three plants; the higher content was E. camaldulensis bark extract and the $C$. spinosa leaves extract had lower content. The results were not consistent with the previous study which revealed that the total alkaloid in the ethanolic extract of E. camaldulensis bark was $400 \pm 0.03 \mathrm{mg} / 100 \mathrm{~g}$ and it higher than other parts [22]. Not all alkaloids can react with the BCG dye, due to the lack of a general method to estimate all types of alkaloids [23], the method described in this study can be used for the determination of a

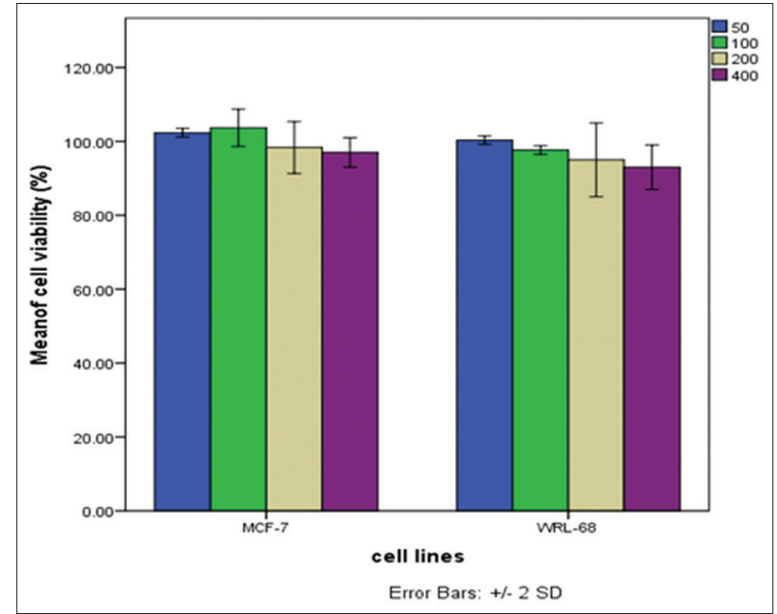

Fig. 3: Cytotoxic activity of the total alkaloids of Aloe vera leaves against the WRL-68 and Michigan Cancer Foundation-7 (MCF-7) cell lines. Extract concentrations ranged from 50 to $400 \mu \mathrm{g} / \mathrm{ml}$ and inhibitory concentration $50 \%$ of MCF-7 was $991.50 \mu \mathrm{g} / \mathrm{ml}$

special group of alkaloids [18]. The BCG can react with a certain class of alkaloids and some alkaloids do not react with this reagent [17].

Cytotoxicity of total alkaloid against MCF-7 and WRL-68 cell lines was performed using a MTT assay, which it is reduced by metabolically active cells, in part by the action of dehydrogenase enzymes, to generate reducing equivalents such as nicotinamide adenine dinucleotide (NAD) and NAD phosphate. The resulting intracellular purple formazan can be solubilized and quantified by spectrophotometer [24].

E. camaldulensis contains many phytochemical compounds have biological activities [11,25]. This study implicit the observation that petroleum ether and chloroform extracts of Pinus and E. camaldulensis showed a promising anticancer activity this compounds that inhibit cancer initiation are traditionally termed (blocking agents). Bioactive components present in plants can prevent carcinogenesis by blocking metabolic activation, increasing detoxification, or providing alternative targets for electrophonic metabolite [26]. They may act by preventing the interaction between chemical carcinogens orendogenous free radicals and DNA; some alkaloid has an activity to inhibits the proliferation of multiple cancer cell lines by inducing cell cycle arrest at the G1 or G2/M phases and by apoptosis [27,28]. Furthermore, another study revealed that alkaloid have ability inhibits breast stem cell selfrenewal without cause toxicity to differentiated cells [29], interacts with DNA or RNA to form an alkaloid-DNA or a alkaloid-RNA complex, respectively, to prevent damage such as berberine make as anticancer by formation complex with DNA and RNA to prevent damage [30,31]. Thereby reducing the level of damage and resulting mutations which contribute not only to cancer initiation but also progressive genomic instability and overall neoplastic transformation. Protection may be achieved as a consequence of decreased cellular uptake and metabolic activation of procarcinogens and/or enhanced detoxification of reactive electrophiles and free radical scavenging, as well as induction of repair pathways [32-35].

Similar studies have found that the methanolic extract of E. camaldulensis bark had cytotoxicity and antitumor activity against Ehrlich's ascites carcinoma (EAC) in Swiss albino mice [36]. Some alkaloid compound, in other hand, had toxic activity to increase proliferation cancer cell at low concentration of an alkaloid extract as shown in Fig. 3. This result was in agreement with the previous studies which revealed the alkaloids of natural herbs that had a side effect lead to the toxicity [37]. Such as piperine lead to neurotoxicity, immunotoxicity, and reproductive toxicity have been reported [38], and hepatotoxicity and embryonic toxicity can also be induced by sanguinarine [39]. The inhibition 
difference in cell viability may be due to the nature of the compounds found in each crude extract and their interaction with metabolic nature of each type cells or may be due to the effectiveness of some enzymes that act as antioxidants especially in cancer cells [40].

\section{CONCLUSION}

Plant alkaloids appeared variable cytotoxic activity against cancer and normal cell lines depending on the alkaloid contents, concentrations, purity, and type of cell lines.

\section{ACKNOWLEDGMENTS}

The authors gratefully acknowledge Faculty of Biology Laboratories for providing essential services to carry out this study. Department of Biology, College of Science, University of Babylon, Iraq.

\section{REFERENCES}

1. Parkin DM, Bray F, Ferlay J, Pisani P. Global cancer statistics, 2002. CA Cancer J Clin 2005;55(2):74-108.

2. Parkin DM, Fernández LM. Use of statistics to assess the global burden of breast cancer. Breast J 2006;12 Suppl 1:S70-80.

3. Iraqi Cancer Board. Results of the Iraqi Cancer Registry 2004. Baghdad: Iraqi Cancer Registry Center, Ministry of Health; 2007.

4. Cragg GM, Newman DJ. Plants as a source of anti-cancer agents. J Ethnopharmacol 2005;100(1-2):72-9.

5. Park YI, Jo TH. Perspective of industrial application of Aloe vera. In: Park YI, Lee SK, editors. New Perspective on Aloe. New York, USA: Springer Verlag; 2006. p. 191-200.

6. Rishi P, Rampuria A, Tewari R, Koul A. Phytomodulatory potentials of Aloe vera against Salmonella OmpR-mediated inflammation. Phytother Res 2008;22:1075-82.

7. Hussain F, Shah M, Sher H. Traditionnal resource evaluation of some plants of Mastuj, Pakistan. Pak J Bot 2007;39:339-54

8. Taifour H, Nawash OS, Al Damen A. Medicinal plants in the Royal botanic garden at tell Ar-Rumman in Jordan. Plant Med 2011;77-PL30. DOI: $10.1055 / \mathrm{s}-0031-1282679$.

9. Joshi B, Sah GP, Basnet BB, Bhatt MR, Sharma D, Subedi K, et al. Phytochemical extraction and antimicrobial properties of different medicinal plants: Ocimum sanctum (tulsi), Eugenia caryophyllata (clove), Achyranthes bidentata (datiwan) and Azadirachta indica (neem). J Microbiol Antimicrob 2011;3:1-7.

10. Panico AM, Cardile V, Garufi F, Puglia C, Bonina F, Ronsisvalle G. Protective effect of Capparis spinosa on chondrocytes. Life Sci 2005;77(20):2479-88.

11. Verdeguer M, Blazquez MA, Boira H. Phytotoxic effects of Lantana camara, Eucalyptus camaldulensis and Eriocephalus africanus EOs in weeds of Mediterranean summer crops. Biochem Syst Ecol 2009;37:362-9.

12. Taylor JLS, Rabe T, McGraw LJ, Jäger AK, Staden J. Towards the scientific validation of traditional medicinal plants. J Plant Growth Regul 2001;34:23-37.

13. Harbone JB. Phytochemical methods. A Guide to Modern Techniques of Plant Analysis. $2^{\text {nd }}$ ed. London. Chapman and Hall; 1984. p. 307.

14. Harborne JB. Phytochemical Methods. $2^{\text {nd }}$ ed. New York: Chapman and Hall; 1984. p. 288.

15. Antherden LM. Textbook of Pharmaceutical Chemistry. $8^{\text {th }}$ ed. London: Oxford University Press; 1969. p. 813-4.

16. Neelima N, Gajanan N, Sudhakar M, Kiran V. A preliminary phytochemical investigation on the leaves of Solanum xanthocarpum. Int J Res Ayurveda Pharm 2011;2(3):845-50.

17. Amanlou M, Khosravian P, Souri E, Dadrass OG, Dinarvand R, Alimorad MM, et al. Determination of buprenorphine in raw material and pharmaceutical products using ion-pair formation. Bull Korean Chem Soc 2007;28:183-90.
18. Fazel S, Monsef H, Ghamooshi R, Verdian-Rizi M. Spectrophotometric determination of total alkaloids in some Iranian medicinal plants. Thai J Pharm Sci 2008;32:17-20.

19. Chih PL, Wei JT, Yuang LL, Yuh CK. The extracts from Nelumbo nucifera suppress cell cycle progression, cytokine genes expression, and cell proliferation in human peripheral blood mononuclear cells. Life Sci 2004;75(6):699-16.

20. Levesque R. SPSS Programming and Data Management: A Guide for SPSS and SAS Users. $4^{\text {th }}$ ed. Chicago: SPSS Inc.; 2007.

21. Edeoga HO, Okwu DE, Mbaebie BO. Phytochemical constituents of some Nigerian medicinal plants. Afr J Biotechnol 2005;4(7):685-8.

22. Sani I, Abdulhamid A, Bello F. Eucalyptus camaldulensis: Phytochemical composition of ethanolic and aqueous extracts of the leaves, stem-bark, root, fruits and seeds. J Sci Innov Res 2014;3:523-6.

23. Fadhil S, Monsef H, Ghamooshi R, Verdian-Rizi M. Spectrophotometric determination of total alkaloids in Peganum harmala L. using bromocresol green. J Pharm 2010;4:275-8.

24. Freshney RI. Culture of Animal Cell. $6^{\text {th }}$ ed. New York: Wily-Liss; 2010.

25. Debbarma J, Kishore P, Nayak BB, Kannuchamy N, Gudipati V. Antibacterial activity of ginger, Eucalyptus and sweet orange peel EOs on fish-borne bacteria. J Food Process Preserv 2013;37:1022-30.

26. Keum YS, Jeong WS, Kong AN. Chemoprevention by isothiocyanates and their underlying molecular signaling mechanisms. Mutat Res 2004;555(1-2):191-202.

27. Sun Y, Xun K, Wang Y, Chen X. A systematic review of the anticancer properties of berberine, a natural product from Chinese herbs. J Anti Cancer Drugs 2009;20(9):757-69.

28. Eom KS, Kim HJ, So HS, Park R, Kim TY. Berberine-induced apoptosis in human glioblastoma T98G cells is mediated by endoplasmic reticulum stress accompanying reactive oxygen species and mitochondrial dysfunction. J Biol Pharm Bull 2010;33:1644-9.

29. Kakarala M, Brenner DE, Korkaya H, Cheng C, Tazi K, Ginestier C, et al. Targeting breast stem cells with the cancer preventive compounds curcumin and piperine. J Breast Cancer Res Treat 2010;122(3):777-85.

30. Islam MM, Suresh KG. RNA-binding potential of protoberberine alkaloids: Spectroscopic and calorimetric studies on the binding of berberine, palmatine, and coralyne to protonated RNA structures. J DNA Cell Biol 2009;28(12):637-50.

31. Li XL, Hu YJ, Wang J. Molecular spectroscopy evidence for berberine binding to DNA: Comparative binding and thermodynamic profile of intercalation. J Biomacromolecules 2012;13(3):873-80

32. Valko M, Leibfritz D, Moncol J, Cronin MT, Mazur M, Telser J. Free radicals and antioxidants in normal physiological functions and human disease. Int J Biochem Cell Biol 2007;39(1):44-84.

33. Yu S, Kong AN. Targeting carcinogen metabolism by dietary cancer preventive compounds. Curr Cancer Drug Targets 2007:7(5):416-24.

34. Kale MA, Bindu SM, Khadkikar P. Role of antioxidants and nutrition in oxidative stress: A review. Int J Appl Pharm 2015;7(1):1-4.

35. Sharma R, Chandan G, Chahal A, Saini RV. Antioxidant and anticancer activity of methanolic extract from Stephania elegans. Int J Pharm Pharm Sci 2017;9(2):245-9.

36. Nabila Z, Enaiat KM, Fatma ZS. Anti-proliferative effect on Eucalyptus camaldulensis against Ehrlich ascites carcinoma (EAC) cells in swiss albino mice in vivo. World J Pharm Res 2015;4(4):272-86.

37. Jin-Jian L, Jiao-Lin B, Xiu-Ping C, Huang M, Wang YT. Alkaloids isolated from natural herbs as the anticancer agents. J Evid Based Complementary Altern Med 2012;2012:12.

38. Dogra RK, Khanna S, Shanker R. Immunotoxicological effects of piperine in mice. J Toxicol 2004;196(3):229-36

39. Chan WH. Embryonic toxicity of sanguinarine through apoptotic processes in mouse blastocysts. J Toxicol Lett 2011;205(3):285-92.

40. Saleh MR, Al-Ataby SM, Al-Samarray YS. The cytotoxicity effect of ethanolic crude extract of Cnicus benedictus L. leaves on the murine mammary adencarcinoma cell line AMN-3. Iraqi J Cancer Med Genet $2015 ; 8(1): 72-8$ 